Justice at the Margins: Notions of Justice in the Punishment of Prostitution

\author{
Sarah Biddulph ${ }^{1}$
}

\title{
Introduction
}

This book explores the many, contested meanings of justice in the People's Republic of China (PRC). It uses the lenses of 'spectacle' and 'text' as ways of analysing notions of justice. The Chinese party-state does not have a monopoly on either spectacles or texts, nor does it control all meanings of justice. However, the party-state retains overwhelming, though not absolute, power in defining and giving effect to its own notions of justice. It has been actively, even aggressively, propagating its own vision of justice, both positively, through law and propaganda, and negatively, by punishing those who dare to propose alternative or contesting visions of justice (as demonstrated by detention and interrogation of hundreds of rights protection lawyers in early 2015).

This chapter uses a close analysis of the legal treatment of the first-party prostitution transaction (sex workers and their clients) to tease out the official vision(s) of justice embedded in both text and practice. ${ }^{2}$ I have chosen to look at notions of justice as they apply to prostitution as this conduct is unlawful and is seen by the authorities as seriously harming social order and undermining socialist morality. And, since the test of a state's commitment to legal justice is found in its treatment of the morally and socially marginalised, the chapter goes on to juxtapose the legalistic vision of justice with the periodic public humiliation of sex workers. How does the legalistic vision of justice relate to this spectacle of state-orchestrated humiliation? At first glance these two appear to be incommensurable. But are they? Does the law turn a blind eye to public humiliation? Is this blindness part of the law's vision of justice? If so, what does it say about the values reflected in the law? The text of the law is one place where the state inscribes its vision of justice, both substantive and procedural. It should be held to account. This chapter seeks to do that.

We might imagine that the law should reflect a coherent of set of values and a coherent view of justice. But if we look at the evolution of the legal regulatory regime governing prostitution and the differing political, ideological and moral attitudes prevailing at the time different parts of it were put in place, we might find that the rules themselves lack coherence. It may also be that the ambiguity of the statement of values contained in the text of the law is convenient for the party-state. In terms of reform, this ambiguity creates the space for the party-state to retain existing punitive powers in the name of protecting social order and morality, or to allow them to wither away in the name of rule of law. To explore the visions of justice in the law, I locate my analysis along two axes. The first is the movement between populist and formal modes of justice. This axis analyses justice in terms of the degree of formal institutionalization of the administration of justice. The second is the movement of legal governance from state-oriented to people-oriented. This axis focuses more on the orientation and values of legal rules themselves. 
Scholars have identified two competing notions of justice that have influenced the ways justice has been administered since establishment of the PRC (Cohen 1966: 477-88; Leng and Chiu 1985; Lubman 1999; 71-87). One is formal and bureaucratic justice based on the Soviet model of socialist legality. Formal modes of justice are given bureaucratic and institutional form through codified laws enforced by a 'regular judicial hierarchy' (Leng and Chiu 1985: 7). This form of legality is seen as favouring stability and predictability in administration as the basis for social order (Bradley 1981: 16).

The second notion of justice - a populist mode - emphasises revolutionary, mass-line justice and relies heavily upon mass mobilisational tactics of campaigns of suppression against class enemies and revolutionary transformation of society based on notions of class struggle (Brady 1981, 1982; Leng and Chiu 1985: 7). Prior to 1979, when class struggle was removed from its central position in the Chinese Communist Party (the 'party') program, the balance between formal and informal modes of justice regularly shifted. The decision to establish a system of governance based on law from 1979 marked a determination to return to formal, bureaucratic modes of justice. Despite this apparent retreat from populist forms of justice, in the reform era we have seen the persistence of techniques of Maoist era populist legality. In an era of increasing formalisation and bureaucratisation of the administration of justice, the continuing embrace of populist techniques poses a challenge to a model that sees formal and informal modes of justice as existing in competition with each other. Instead, I suggest below that populist forms of justice we see in operation today should be understood as existing within the current model of formal legality and reflecting values of the formal legal system.

The second axis of analysis is constituted by the movement between state-centred and people-centred modes of governance. State-centred governance is often associated with the Soviet-inspired notion of law as serving to empower state agencies. Law both empowers and enables state agencies to carry out their enforcement functions. That form of law could thus reasonably enact broad discretion and weak procedural requirements, and limit the capacity of individuals to initiate supervision over enforcement practice, except to the extent that supervision suited the political needs of higher-level state agencies. In the area of sanctions, it favours empowerment of officials to investigate and punish crime and other forms of anti-social behaviour in the interests of the state and the collective, over protecting individuals against abusive or illegal enforcement practices.

From 2003, the party has embraced the idea of people-centred governance (yi ren weiben 以人为本), which has been associated with the notion that law should value humanism and reflect the interests of the people. The law should provide protection for individual human rights. This form of law would limit discretionary powers of the public security agencies (also referred to as the 'police'), strengthen mandatory procedural requirements that enhance openness, timeliness and proportionality in enforcement practices, and strengthen both the oversight and legal sanctions for illegal enforcement activities such as extracting evidence using torture. Whilst a range of reforms have been made in the name of people-oriented governance, it is still too early to suggest that these reforms 
are either intended to, or in fact do, impose meaningful fetters on the substantive powers and procedural flexibility of enforcement agencies.

Ultimately, this chapter queries whether our conception of these elements of justice should be characterised as one of movement toward formal, bureaucratic justice and toward embracing the human-rights promises of a people-oriented form of governance. The chapter argues that it is probably more useful to conceive of notions of state-centred and peoplecentred governance as coexisting, and that they in turn encompass elements of both populist and formal legality. Part of the incoherence of the legal rules for sanctioning prostitution, it argues, is that one institutional form does not displace the other and one set of legal values does not displace the other, but that these seemingly contradictory elements coexist.

This chapter engages in a detailed analysis of both the legal framework of punishments (the legal shape of substantive justice) and the rules that prescribe the ways in which the police must exercise their powers (the legal shape of procedural justice) to identify how these views of justice are represented. The chapter proceeds as follows. First, it gives an account of the use of public humiliation of sex workers by public security officials, the spectacle against which legal notions of justice must be read. It then gives a brief account of the historical background to the present-day regulatory framework, before engaging in a detailed textual analysis of the laws, regulations and rules governing the sanctioning of prostitution and providing a legal critique of those rules. It discusses the two axes of justice against which the regulation of prostitution is evaluated. Finally it discusses proposals for legal reform of sanctioning powers for prostitution, and concludes by considering what the rules and enforcement practice reveal about official concepts of justice.

Whilst there has not been significant legal reform in punishment of sex workers to date, this is not a static topic, as decisions of the Central Committee of the party in both 2013 and 2014 have placed the legal structure of punishments in the spotlight. It is thus timely to unpack the vision of justice currently embedded in the law if a transparent discussion about legal values is to be had in relation to reform proposals. The reform-era campaigns against vice that include humiliation of sex workers are framed within a legal context and are said by some to operate 'in accordance with the law'. The study considers whether this is so and examines how the spectacle and text inter-relate in China today.

\section{The Spectacle of Debasement}

In July 2010, Dongguan police paraded two sex workers through the streets. They were handcuffed and tethered by a long rope tied around their waist. As photographs were reposted online, many netizens criticised this form of public humiliation (Gillet 6 August 2010; Jacobs 27 July 2010; Wang 10 February 2014; Xie October 2010). The police responsible were subject to nationwide criticism and the officer responsible was reported to have been suspended for a month (Gillet 6 August 2010; Xie October 2010). On 27 July 2010, the Ministry of Public Security (MPS) issued a notice prohibiting public humiliation of sex workers (Dui Hua 29 July 2010; Gillet 6 August 2010; Jacobs 27 July 2010). 
Public humiliation of sex workers is not new. A similar public uproar occurred in 2006 in Shenzhen when over 100 sex workers and their clients were subjected to very public humiliation. Labelled the 'Futian incident', it was subject to intensive media attention and wide-ranging criticism by lawyers, academics, the Women's Federation and the general public (Jeffreys 2012a: 114-22). At the time the public response was mixed, as spectators were reported as 'looking on with interest' (Watts 6 December 2006) and some were 'applauding' (Jeffreys 2012b: 147). Overwhelmingly, though, public opinion was critical of such public shaming. Public censure of shaming rituals such as these and official attempts to justify such conduct exposes the divisions that exist within government and party agencies, as well as in public views and values.

In the face of these injustices and indignities, it is easy to dismiss the law or ignore it as irrelevant. I argue that this is a mistake as it elides two distinct problems. The first is to assume that the law (read broadly to cover laws, regulations and other regulatory documents such as normative documents [guifanxing wenjian 规范性文件]) does not say anything meaningful about the scope and procedures for imposing punishments on sex workers and their clients. The second is to assume that the police consistently act in breach of the law or ignore it. But if we examine carefully what the law actually provides and does not provide, we might find that the law is deeply implicated in abusive practices, either through its failure to articulate a clear scope, standards or procedures for investigation and imposition of punishments including detention, or through remaining silent on humiliation. We might also find that the police are not doing anything (or as many things as we may think are) unlawful if the law fails to define and constrain, or even authorises certain practices.

In her analysis of the Futian incident, Elaine Jeffreys argues that publicly parading sex workers in the reform era should be distinguished from and should not be seen as a revival of the modes of populist justice performed in the Maoist era. Today's forms of public degradation and humiliation are now, she argues, both authorised and bound by the law (Jeffries 2012b: 126-8). In fact her assessment of this incident was that the police had acted in keeping with Chinese law' (Jeffries 2012b: 151). This assertion invites us to consider the text of the law carefully to examine both its prescriptions and its silences. Is it lawful for police to parade sex workers in public, even if their faces are covered by a mask and their full names are not read out (as was the case in the Futian incident)? Which legal prescriptions guide and constrain the ways in which policing powers are exercised? What are the legal parameters of justice in China? Which conclusions can we draw about the character of justice these parameters instantiate; populist and formal, and state-centred and people-centred? And do these legal rules tell us about the party-state's legally defined notion of human rights, particularly human dignity?

A brief look below at the evolution of regulation proscribing and punishing prostitution highlights the different political and social contexts in which that regulatory regime was put in place and how it came to be that the legal texts governing prostitution do not necessarily reflect a coherent set of values or a coherent view of justice. 


\section{The Historical Context}

Incoherence in the rules sanctioning prostitution should be understood in the historical context of the official attitude toward prostitution. In Imperial China (prior to being outlawed by the Yongzheng Emperor in 1723), prostitution was not outlawed amongst the so-called debased classes. In fact Sommer argues that imperial policy including official administration of prostitution amongst the debased classes $^{3}$. and prohibition amongst commoners was designed to create and reinforce social class differences, and was an attempt to impose 'a certain vision of moral order' (Sommer 2000: 215).

In the early 1950s, the new PRC government sought to impose a new vision of moral order. At that time prostitution was characterised as a 'feudal remnant' to be eradicated. The prevalence of prostitution in the 1950s was ascribed to poverty and the feudal repression of women (Herschatter 1997: 305; Zhan 2005: 416). The party-state was able to launch a comprehensive campaign to eradicate prostitution, using mass mobilisation, propaganda, detention, comprehensive local surveillance and re-employment strategies to great effect (Biddulph 2007: 76). Success was claimed, and official accounts proclaimed that prostitution was no longer a problem. However, if this account was ever a fact, it certainly did not remain one, as from the late 1970s prostitution re-emerged and expanded dramatically. Whilst policies were implemented to eradicate prostitution for a second time, it quickly became clear that the social and regulatory environment had changed so much that complete eradication was no longer possible (Jeffries 2012a: 157). From the point of view of official ethics, today's sex workers are distinguished from those of the 1950s. In a 1987 report, sex workers were recharacterised as lazy, seeking material enjoyment and 'pursuing a degenerate parasitic lifestyle'. ${ }^{4}$. Their conduct continues to be seen as causing serious harm to social order (Zhan 2005: 417). Prostitution and sex workers, the act and the actors, have been thus placed clearly outside the moral boundaries of society. Whilst prostitution has not been characterised as a criminal offence, the social harm continues to be considered serious: poisoning the social atmosphere, undermining the construction of a socialist spiritual civilization and contributing to increasing crime (Wang, Xia, and Lei 1997: 20).

Periodic campaigns have been waged against prostitution. The most prominent was the Six Evils campaign launched in November 1989 in the wake of the social and political crisis precipitated by the Tiananmen Square massacre. The Six Evils campaign targeted pornography, prostitution, drug use, gambling, deceiving the people using feudal superstition, and kidnapping and selling women and children (Biddulph 2007: 162-3). From this time, leadership over anti-prostitution and pornography policy has been directed by the National Anti-pornography Leading Group (Saohuang Dafei Gongzuo Xiaozu 扫黄打非工作小组), which continues to coordinate the work of party and government agencies in this area.

Public crackdowns continue. A recent illustration of such a crackdown was that waged in Dongguan city beginning in February 2014 (Wong 6 March 2014). An undercover CCTV investigation aired nationally in early February 2014 exposed prostitution in a number of entertainment venues in Dongguan. This exposé attracted national attention as well as the 
ire of the MPS. The demanded that the Dongguan public security launch a concerted action to strike hard against prostitution in that city. As a result, 67 people were arrested and 12 entertainment venues closed on 9 February 2014 (Wang 10 February 2014). The MPS also determined that the 'protective umbrella' for this conduct provided by officials be investigated and punished. The MPS recommended official action be taken against responsible officials for dereliction of their official duty. On 14 February the Guangdong Party Standing Committee met and determined to remove from their posts the Dongguan Vice Mayor and the Chief of the Municipal Public Security Bureau, as well as the Municipal Public Security Deputy Party Secretary and Deputy Chief (Xing 17 February 2014). The MPS went on to demand that police forces throughout the country learn the lesson from Dongguan and take concerted action to crackdown on the vices of prostitution, gambling and illegal drugs (Xing 17 February 2014). This time the hard strike against vice faced in two directions; one was toward the legally proscribed conduct and the other was toward the police forces responsible for its investigation and punishment (Xing 17 February 2014). In response, nine provinces and 16 cities throughout China launched a specialised struggle against vice (Xing 17 February 2014). Again in 2014 the police conducted a campaign against gambling and prostitution entitled Operation Silent Storm (无声风暴) in which they claimed to have caught 87,000 offenders (Law Yearbook Editorial Committee 2015). But, despite continuing crackdowns, in these and other highly publicised cases, such as that of Huang Haibo (discussed below), the public attention that accompanies them is not always welcome by front-line police who bear the brunt of public ire and the risk of punishment both for carrying out and failing to carry out higher level instructions.

, At least from the mid-2000s, enforcement objectives have also become more multifaceted. Campaigns of suppression and punishment became tempered by the needs of public health programs designed to reduce the transmission of HIV and sexually transmitted infections. Efforts to characterize policies to suppress prostitution and to promote safe sex practices in prostitution as 'complementary not contradictory', reveals a greater understanding that suppression campaigns interfere with effective implementation of harm reduction programs (Jeffries 2012a: 157). That said, propaganda around condom use and harm reduction programs has not prevented ongoing campaigns of suppression that attack prostitution as a social harm (Jeffries 2012a: 158).

Legally, the position of sex workers is precarious in two distinct ways. The first is their vulnerability to punishment. Though first-party prostitution is generally not characterised as a criminal offence, it is nevertheless unlawful and is punishable with a number of administrative punishments, all of which are imposed by the public security agencies. The second is their inability to call on the law to seek protection or redress against wrongs to their person and property. Sex workers are subjected to a wide range of unlawful and abusive conduct at the hands of people they encounter on a daily basis: clients, brothel owners, pimps, police, and officials from the health bureau. The unlawfulness of their conduct in providing sexual services, and their marginalisation from mainstream society, thus in practice also place 
them outside the protection of the law in respect of these other types of wrong (Boittin 2013; Tucker, Ren and Sapio 2010).

\section{Rules Governing the Punishment of Sex Workers and Their Clients in China Today Substantive Regulation}

Neither prostitution itself nor using sex workers by itself constitutes a criminal offence. Instead, sex workers and their clients may be subject to a range of administrative punishments imposed by the police. The police are authorised to impose an administrative fine or administrative detention under the Public Security Administrative Punishments Law 2006 as amended in 2012 (PSAPL Zhi'an Guanli Chufa Fa 治安管理处罚法). They may decide to impose a period of detention for education (shourong jiaoyu 收容教育 (shoujiao), of between six months and two years under the 1991 National People's Congress (NPC) Standing Committee Decision on Strictly Prohibiting Prostitution and Using Prostitutes (Guanyu Yanjin Maiyin Piaochang de Jueding 关于严禁卖淫嫖娼的决定) (1991 Standing Committee Decision). Prior to its abolition in December 2013, where a person had already been sanctioned for sex work or using sex workers, they could have been subject to a period of detention under reeducation through labour (laodong jiaoyang 劳动教养 (Iaojiao 劳教) of between one and three years. In a limited range of circumstances, a criminal punishment may be imposed under the Criminal Law (Xing Fa 刑法) in respect of a number of prostitution-related offences.

There are three notable features of this punishment landscape. The first is that power to initiate, impose and administer these administrative punishments is concentrated in the hands of the police. The second is the regulatory regimes governing these punishments grant the police broad discretion in determining which of these punishments to impose and within each type of punishment, its degree of severity. The third is that punishments are regulated by a mixture of laws and subordinate regulations. The legislative hierarchy set out in the Legislation Law 2000 as amended in 2015 (Lifa Fa 立法法), requires that subordinate regulations not be inconsistent with higher level laws. But as the discussion below shows, the problem with subordinate regulations is not simply a question about inconsistency, but also about the permissible scope of interpretation through which subordinate regulations purport to limit the scope of operation of superior level legislation.

The comprehensive legislative schema for punishment of prostitution and prostitution-related conduct was first set out in the 1991 Standing Committee Decision, which was passed to give legal effect to the campaign to strike hard against the Six Evils. Paragraph 4 sets out a range of administrative measures from fines, administrative detention, shoujiao to laojiao that may be taken in respect of sex workers and clients of sex workers (maiyin piaochang 卖淫嫖娼). It both refers to other laws that authorise punishment (paragraph 4.1) and authorises punishments (paragraph 4.2, 4.3 and 4.4).

Para 4.1 authorises imposition of a fine by providing: 
In respect of prostitution and using prostitutes, impose a fine in accordance with Article 30 of the Security Administrative Punishments Regulations (now Article 66 of the PSAPL, discussed below).

Para 4.2 authorises shoujiao in the following terms:

Those who prostitute or use prostitutes may be coercively gathered up by the public security organs in conjunction with other relevant departments to carry out legal and moral education and to engage in productive labour to give up this evil habit. The time limit [for detention] is between six months and two years. The State Council will pass specific measures [for implementation].

Para 4.3 authorises imposition of laojiao for repeat offenders:

Where prostitutes and clients of prostitutes who have already been punished by the public security organs are caught again, impose laojiao and impose a fine of RMB 5,000.

Para 4.4 authorises compulsory testing and treatment:

Prostitutes and clients of prostitutes are to be subject to compulsory testing for sexually transmissible infections (STI). Where they are found to have a sexually transmitted infection they are to be subject to compulsory treatment.

As well as specifying a range of administrative sanctions, this decision also set out criminal punishments for a range of offences including organising prostitution, coercing others into prostitution, or threatening, injuring, or killing prostitutes. These provisions were subsequently incorporated into the Criminal Law.

\section{Public Security Administrative Punishments Law ('PSAPL')}

Administrative punishments for prostituting or using sex workers are imposed under the PSAPL, Article 66. Article 66 divides punishment into two categories. The first is where the circumstances are minor (including soliciting in a public place), in which case police may impose a fine of up to RMB 500 or administrative detention of up to five days. In other circumstances the person may be punished by between 10 and 15 days administrative detention and a police-imposed fine of up to RMB 5,000. The law itself does not prescribe what types of circumstances are relevant in determining whether the circumstances are minor, leaving this question for the police to determine in each case. ${ }^{5}$

The PSAPL at Article 76 provides that where a person commits any of the acts set out in Articles 67 (introducing a person into prostitution), 68 (creating, transporting, copying, selling or renting pornographic materials) or 70 (gambling), if he or she refuses to correct the behaviour despite repeated warnings, he or she may be subject to a 'compulsory education 
measure' as provided for by the state. This provision is directed against those who have been punished repeatedly to educate them and to correct their offending behaviour, but who refuse to reform (lujiao bugai 屡教不改). The provision itself does not specify what constitutes a 'compulsory education measure'. It may refer to two possible powers that existed when the law was passed, and which have been described by the police as compulsory measures for education, transformation and reform. The first is shoujiao, which I discuss in more detail below. The second (before its abolition) was laojiao. However, it is worth noting that Article 76 does not include a reference to Article 66 that concerns prostitution or using sex workers. So, contrary to common assumptions, Article 76 does not authorise imposition of coercive education measures for prostitution under either shoujiao or laojiao.

\section{Detention for Education (Shoujiao)}

The legal definition of the substantive scope of the power of shoujiao continues to be that set out in the 1991 Standing Committee Decision. Slightly more regulatory detail was provided in the 1993 State Council Measures for Detention for Education of Prostitutes and Clients of Prostitutes (Maiyin Piaochang Renyuan Shourong Jiaoyu Banfa 卖淫嫖娼人员收容教育办法). These measures were subsequently revised on 8 January 2011 (2011 State Council Measures). 6 . The measures describe detention for education as an 'administrative compulsory education measure to gather up prostitutes and their clients to carry out legal and moral education, organize them to participate in productive work, and to carry out testing and treatment for sexually transmitted infections' (Article 2). They go on to provide that shoujiao may be approved by the county level (or any level above) public security bureau (Article 8).

\section{Laojiao}

Imposition of a term of laojiao on sex workers and their clients was authorised by para 4.3 of the 1991 Standing Committee Decision where there had been repeated infringements. The MPS passed regulations in 2002 consolidating and expanding the scope of conduct that may be punished by a term of laojiao. These regulations, Regulations on Public Security Organs Handling Re-education through Labour Cases (Gong'an Jiguan Banli Laodong Jiaoyang Anjian Guiding 公安机关办理劳动教养案件规定) replicated paragraph 4.3 of the 1991 Standing Committee Decision at Article 9(8). All of these rules, to the extent they authorised imposition of a term of laojiao, were rescinded by the NPC Standing Committee Resolution on Abolishing Laws and Regulations on Re-education through Labour (Guanyu Feichu Laodong Jiaoyang Falu Guiding de Jueding 关于废除劳动教养法律规定的决定) issued on 28 December 2013.

\section{Criminal Law}

A limited range of conduct relating to prostitution constitutes a criminal offence. The Criminal Law creates an offence in respect of people who organise, assist to organise, coerce people into prostitution, or who injure or kill those forced into prostitution (Article 358), those who harbour, assist or entice a person into prostitution (Article 359), and those who prostitute or buy services from prostitutes knowing that they have a sexually transmissible infection or that 
the prostitute is under 14 years old (Article 360). People who work in certain industries such as hotels, restaurants, the entertainment industry or taxi companies, who take advantage of a position in a work unit to entice or organise, coerce, harbour, or introduce people into prostitution, or give a tip off of a police raid on prostitution, are punishable under Articles 361 and 362 of the Criminal Law.

\section{Legal Categories and Procedural Rules}

In the increasingly dense thicket of rules governing the exercise of administrative powers, the question of the legal characterisation of the powers exercised by the police to sanction prostitution is important in determining what, if any, mandatory procedural rules apply. The artificial categories created by law become significant where the law makes different provisions in respect of procedures and accountability measures depending on the legal classification of the sanction. The first level of division is between criminal and administrative measures. As discussed above, as first-party prostitution is generally not characterised as a criminal offence, the bulk of powers used to sanction first-party prostitution are characterised as administrative in nature, so criminal procedure is not discussed here.

Within administrative powers, there are arguably now three relevant legal categories: punishments (chufa 处罚), coercive measures (qiangzhi cuoshi 强制措施), and more controversially, 'handling measures' (chuli cuoshi 处理措施). The procedures and standards for imposition of each are governed by a different configuration of intersecting laws and rules. Imposition of a fine or a period of administrative detention under the provisions of the PSAPL is classified as an administrative punishment. Consequently the procedural rules set out in the Administrative Punishments Law (Xingzheng Chufa Fa 行政处罚法) and the PSAPL apply. Administrative coercive measures are governed by the 2012 Administrative Compulsion Law (Xingzheng Qiangzhi Fa 行政强制法) (the term 强制 is also sometimes translated as 'compulsory'). The existence of a third category of administrative powers, administrative 'handling measures', is not reflected in national level legislation (there is no law on administrative handling measures). It is instead a concept found in the 2012 MPS Regulations on the Procedures for Handling Administrative Cases by Public Security Organs (the 2012 MPS Regulations) (Gong'an Jiguan Banli Xingzheng Anjian Chengxu Guiding 公安机关办理行政案 件程序规定), which is discussed in more detail below.

The 2012 MPS Regulations, originally passed in 2003, govern all administrative powers exercised by public security organs. As subordinate legislation, the Constitution and the Legislation Law require that these regulations not be inconsistent with higher level legislative instruments. So, they have been revised periodically (in 2006 and again in 2012) to bring them into line with recent legislative changes and to regularise procedures for handling administrative cases. According to an MPS spokesperson, the 2012 revision was designed to respond to party, government and public demands for better protection of the lawful rights of citizens and to improve the justice of law enforcement practices, to make the regulations consistent with recent legal developments including the 2008 Drug Prohibition Law (Jin Du Fa 
禁毒法) and the Administrative Compulsion Law, and to regularise law enforcement procedures and practices (Zou and Shi 5 January2013).

The three legal categories are particularly significant in respect of shoujiao. Whilst there has been some discussion about the appropriate legal characterisation of shoujiao, most now concur that it is not an administrative punishment. It is also not explicitly included within the scope of the Administrative Compulsion Law which merely includes a general category of 'administrative coercive (or compulsory) measures that restrict personal freedom' at Article 9(1).

The 2012 MPS Regulations purport to exclude shoujiao from the scope of both administrative punishments and administrative coercive measures through the concepts of 'administrative cases' and 'handling measures'. Administrative cases are defined to comprise both administrative punishments and 'handling measures'. Handling measures are described as including 'coercive quarantine for drug rehabilitation, detention for education (shoujiao) etc.' Coercive measures are separately regulated in 2012 MPS Regulations Article 12, which sets out the types of coercive measures that may be taken in handling 'administrative cases'. The schema of these regulations thus clearly distinguishes shoujiao, an administrative handling measure, from both administrative coercive measures and administrative punishments. This treatment is not accidental. It tells us something about the very formalistic face of Chinese law that carves off areas of police power and shields them from the fetters gradually imposed by legislation.

Arguably the MPS does not have the power to determine the legal character of the powers it administers. Nor does it have the power to issue a rule to limit the scope of superior level legislation. Rules and regulations are merely to provide the detail necessary to implement laws and administrative regulations (Legislation Law Article 80). However, this is not the first time the MPS has modified the scope and application of legislation by way of implementing rule. ${ }^{7}$. There are two important regulatory problems; legality, and that these rules have been allowed to stand. The practical problem is that the MPS continues to define the laws applicable to the exercise of powers like shoujiao without question or challenge.

Formal distinctions between punishments, coercive measures and possibly now a new category of 'handling measures' have been used effectively by the police to avoid procedural constraints upon the exercise of shoujiao and other administrative detention powers within its jurisdiction. Another example of this disjuncture was laojiao. Even though the 1991 State Council White Paper on Human Rights in China characterised laojiao as an administrative punishment, the MPS continued to insist that it was not an administrative punishment but a coercive measure for education and rehabilitation. In practice, where the distinction had legal consequences such as in administrative litigation cases, laojiao was not treated as an administrative punishment, but as a sui generis administrative power. 


\section{Procedures}

Basic Principles

In terms of general principles, the procedural rules set out in the Administrative Punishments Law (APL) have acted as a basic template for other legislation such as the PSAPL and the Administrative Coercion Law. The 2012 MPS Regulations also largely replicate the basic procedural rules in the Administrative Punishments Law and the PSAPL in respect of both police administrative punishments and administrative handling measures. In the account below, where the 2012 MPS Regulations provide differential treatment of punishments and handling measures, these are noted.

At face value these rules appear to adopt people-oriented values of articulating and protecting the rights of individuals who might be subject to punishment. Both the PSAPL and the APL require that punishment be proportional to the degree of social harm caused by the act, and that they are imposed in a manner that is timely, just, open and based on facts. The imposition of punishments must respect the human rights of the individual subjected to punishment (PSAPL Article 5). With the important exception of proportionality, these principles are replicated in the 2012 MPS Regulations at Articles 3 and 4.

Openness requires that, before imposition of a punishment, the official must inform the accused party of the facts, evidence, and law upon which the decision is based, and must give reasons for the decision (APL Article 31). That party is permitted to respond to the facts and evidence of the accusation, provide contradictory or mitigating evidence, and debate the basis for the decision without being liable to having their punishment exacerbated for doing so (APL Article 32; PSAPL Article 94). The public security agency is required to check the facts, reasons and evidence provided by the alleged violator and take these into account in decisionmaking (APL Article 32; PSAPL Article 94; 2012 MPS Regulations Article 65).

The PSAPL Article 113 prohibits the police from beating, abusing, or humiliating people in implementing public order punishments under that law (dama, nuedai, wuru 打骂, 虐待, 侮辱). ${ }^{8}$ Administrative punishments of sex workers imposed under the PSAPL thus prohibit public humiliation. Unfortunately such an explicit prohibition is absent from the 2012 MPS Regulations, which remains silent on humiliation.

\section{Summary Procedure}

Following the scheme set out in the APL, the PSAPL and the 2012 MPS Regulations there are three types of mandatory procedure for handling administrative cases: summary, ordinary and hearing procedures. Only ordinary procedures apply in sanctioning prostitution. Summary procedures, enabling the punishment to be given on the spot, apply in respect of warnings and fines of individuals up to RMB 50 and legal entities of up to RMB 1,000 (APL Article 33; 2012 MPS Regulations Article 34). Police are now prohibited from imposing on-the-spot fines in cases involving prostitution, introducing or inducing a person to prostitute, or using prostitutes (2012 MPS Regulations Article 34 (4)). 


\section{Ordinary Procedure}

Ordinary procedure applies in respect of sanctions that may be imposed on sex workers and their clients. On its face, the detailed prescriptions in the law reflect a legal affirmation of the basic principles of procedural justice.

In investigating 'administrative cases' using ordinary procedure (which is defined to include shoujiao), two police are required to be present and show their identity badges (APL Article 37; 2012 MPS Regulations Article 40). They may collect physical and documentary evidence (2012 MPS Regulations Article 23) about the facts of the alleged violation including time, location, circumstances of the conduct, evidence about the alleged perpetrator, and aggravating and mitigating circumstances (2012 MPS Regulations Article 38). Investigation and evidence gathering must be conducted in a manner that is 'complete, objective and just' (APL Article 36; 2012 MPS Regulations Article 37). The PSAPL makes the same requirement in respect of a search of premises, but no such explicit requirement is imposed in respect of interrogation (Article 87). Evidence is to be reviewed by the head of that administrative agency (APL Article 38).

Police may use compulsory measures against both property and the person during their investigation under the provisions of the 2012 MPS Regulations. Compulsory measures against property such as goods, facilities or locations include: impounding (kouya 扣押), detention (juliu 扣留), temporary seizure (linshi chafeng 临时查封), seizure (chafeng 查封), registration and protection (xianxing dengji baocun 先行登记保存), and sampling for evidence (chouyang quzheng 抽样取证) (Article 42(1)). They are required to register, store and ensure the return of any property confiscated in the course of investigation that is not related to the case (Article 41). Compulsory measures against a person suspected of being engaged in sex work or of being their client include: protective detention (qu baohuxing yuesu cuoshi 取保护性约束措施), detention for further questioning (jishu panwen 继续盘问), compulsory summons (qiangzhi chuanhuan 强制传唤), compulsory testing (qiangzhi jiance 强制检测), detention for the purposes of investigation (juliu shencha 拘留审查), and compulsory measures to restrict the scope of activities (xianzhi huodong fanwei deng qiangzhi cuoshi 限制活动范围等强制措施) (Article 42(2)).

The PSAPL and the 2012 MPS Regulations each make provisions to limit the amount of time a person may be held for interrogation and to constrain the use of torture or trickery to obtain evidence. The PSAPL (Article 79) and the 2012 MPS Regulations (Article 24) provide that evidence gathered by trickery or torture, or which is otherwise unlawfully obtained, cannot be used as the basis of the decision. The 2012 MPS Regulations also provide that a person may not ordinarily be held for questioning for longer than 12 hours, but allows for extensions of up to 48 hours in some circumstances. ${ }^{9}$. Interrogations must be complete within eight hours, unless the matter is complex, in which case an extension of up to 24 hours can be obtained (PSAPL Article 83; 2012 MPS Regulations Article 55). Interrogation of suspects must be carried out in a designated case-handling area within the public security organ. Suspects must be allowed 
appropriate food and rest, and the provision of these items must be noted on the record of interview (2012 MPS Regulations Article 57). A record of the interview is to be made and signed by the person being interviewed. The police may also make audio and video recordings of the interview (2012 MPS Regulations Article 63). The PSAPL (Article 93) provides that a person may not be subjected to an administrative punishment on the basis of an oral confession where there is no other corroborating evidence, thus weakening the incentive to obtain an oral confession at any cost.

Decisions, whether made under summary or ordinary procedure, must be in writing (APL Article 38) and specify the details of the person to be punished, facts and evidence of the violation, grounds for punishment and manner in which the punishment is to be executed, the date of the decision, and they must specify the details of the right to request review of litigation of the decision (PSAPL for summary procedure Article 101, for ordinary procedure Article 96; Sun 2012: 51). The written decision must be delivered on the spot, if possible, to the person to be punished (APL Article 40; PSAPL Article 97). Administrative detention can be decided only by county level and above public security or entry and exit police (Zou and Shi 5 January 2013).

\section{Hearing Procedure}

The third type of procedure is the hearing procedure, where a suspect may request an administrative hearing prior to imposition of a serious administrative punishment. Despite deprivation of personal liberty arguably being the most serious punishment of all, both administrative punishments and administrative handling measures that involve imposition of a period of detention are excluded from the scope of the hearing procedure. Instead a hearing is available in cases involving an order to stop production, revocation of a licence or permit, or imposition of a relatively large fine. A relatively large fine for an individual is an amount in excess of RMB 2,000 (SAPL Article 98; 2012 MPS Regulations Article 99). Where a person is dissatisfied with a decision to impose a period of detention, their recourse is to administrative review or litigation only after the decision has been made.

\section{Other Rules Governing Detention for Education}

The account above indicates that the 2012 MPS Regulations provide a comprehensive set of rules governing all stages of investigation, evidence gathering and decision-making in handling 'administrative cases'. Even though these are subordinate rules, they provide a detailed regulatory framework that is only sketched out by higher-level laws and administrative regulations. This is particularly the case with respect to shoujiao.

The highest level legal instrument authorising shoujiao, the 1991 Standing Committee Decision, does not specify any procedures at all, beyond the idea that targets of this power are to be 'gathered up' by the public security organs. The 2011 State Council Measures are primarily concerned with procedures for admission to and operation of shoujiao facilities. Where these measures do make provisions in respect of decision-making, they are brief. At Article 8, the 2011 State Council Measures provide that the decision to impose detention for education is made by 
the county-level public security organ (and not the local police station). A Decision on Detention for Education Form (shourong jiaoyu jueding shu 收容教育以决定书) must be completed, and a duplicate of this document must be provided to the detainee. Within 15 days of the decision, the family, work unit and the police station in the place of their household registration must be notified. Article 20, which was added in 2011, provides that if a person is dissatisfied with a decision to impose shoujiao they can ask for administrative review of that decision, and if dissatisfied with the review decision, can commence administrative litigation.

However, as the critique below demonstrates, from the perspective of legal protection of individual rights, there remain substantial weaknesses in the law itself and a yawning gulf between law and practice.

\section{Critiques of the Rules}

Critiques of Enforcement Practice: Uncontrolled Discretion and Interchangeability of Punishments

The above account of the substantive scope of administrative powers to punish prostitution describes police discretion to impose a fine of between RMB 500 and RMB 5,000, and/or to impose detention of between five days and two years.

Preferred policing practice has been to impose fines rather than detention unless a concerted crackdown has been ordered (Biddulph 2007: 176; Fu and Choy 2009: 193-5). In a period when local finances are inadequate to fund the increasingly large number of governance responsibilities given to lower levels of government (Wong 2013) imposition of fines has many advantages, not least of which has been the indirect revenue flowing back to the local police agency. Fines are also administratively simpler to impose than administrative detention, which requires decision-making and appropriate documentation be completed and signed by the police chief at county level, notification of family, work unit and local police station, as well as compliance with the procedures for delivery of the detainee to either a detention centre or the shoujiao centre.

The broad discretion given to police under SAPL Article 66 as to the amount of the fine and the number of days of administrative detention that may be imposed enables them to fine or detain at the heaviest end of the prescribed range. One commentator suggests that in practice the lightest fine is imposed infrequently; much more common are fines between RMB 2,000 and RMB 3,000 (Chen 2013: 293). Research in the Guangdong province between November 2013 and February 2014 revealed that police impose the maximum fine of RMB 5,000 as a matter of common practice (Xue 14 May 2014). A number of reasons were identified: it is a convenient way of fulfilling the quota of fines, those subject to punishment did not object as they did not want to draw attention to themselves and cause trouble with the police, and it is legally difficult to determine which circumstances are minor and which are not (Xue 14 May 2014). As a consequence, the broad and unprincipled discretion created by law enables the heaviest fine to be imposed lawfully even if the reasons for doing so are extra-legal. 
Despite a strong preference for imposing fines, there is also a significant number of people who are detained. There is a suggestion that where a person is unable to pay a fine, or where they lack the necessary personal connections to the local police, they will be detained instead of being fined (Liu, Jia, and Qu 9 April 2014). They may be detained under either or both administrative detention (for up to five days or between 10 and 15 days) and shoujiao (for between six months and two years). Even though regulations require the police to inform a person in advance of the evidence and law upon which a decision to impose a period of shoujiao is based, this rarely happens in practice (Sun 2012: 51). The legal mechanisms of administrative litigation and review, which are supposed to hold agencies to account for their failure to comply with procedural rules, remain an ineffective way of supervising police decisionmaking. Police can ignore those rules largely with impunity in handling particular cases.

As the recent, well publicised, case of Huang Haibo illustrates, the police have a broad discretion in determining which form of detention to apply and the length of that period of detention. According to reports, Huang Haibo was caught in flagrante with a sex worker on 15 May 2014. Initially a 15-day period of administrative detention was imposed. Upon expiry of that period, both Huang Haibo and the sex worker, Liu Xinyu, were given a six-month period of shoujiao. After their release on 1 December 2014, Liu Xinyu was immediately subject to criminal detention and questioned on suspicion of enticing a person into prostitution under Criminal Law Article 359 (Zhang and Liu 1 December 2014). On 11 May 2015 she was convicted and sentenced to six months' fixed-term imprisonment, fined RMB 3,000, and ordered to repay $\mathrm{RMB} 3,000$ of illegally obtained income (Wang 12 May 2015). Huang was thus punished by two separate forms of detention for the same conduct: administrative detention and shoujiao. Liu was also administratively punished twice under administrative detention and shoujiao and then given criminal sanctions of a further six months' imprisonment, a criminal fine and confiscation of unlawfully obtained income.

This case illustrates the extent to which administrative punishments of fines, administrative detention and shoujiao may be imposed interchangeably or sequentially. The law is implicated through its lack of specificity in setting out criteria to determine which form of punishment should be imposed and by creating many, overlapping sanctions. The factors taken into account, legal or extra-legal, in determining which punishment to impose cannot be known by anyone outside the decision-making process, including the person being punished. Police are not required to explain to anyone why they chose to impose detention instead of, or as well as, a fine, why they chose to impose a 15-day period of detention instead of a lesser period, and why they imposed two forms of detention rather than one. The procedural rules discussed above require that reasons be given only for a particular decision. So, for example, a decision to impose a period of administrative detention may be justified in the decision notice on the grounds of selling sex at a certain place at a certain time. So too may a decision to impose a fine. As the basis for punishment is prostitution or using prostitutes, the only real hurdle for the police is to show that a prostitution transaction took place. ${ }^{10}$ 
The regulatory regime thus provides no detailed guidelines on type and severity of the punishment to be imposed. So the determination of the length of detention, types of detention and extent of the fine to be imposed depends upon the subjective view of the police officer responsible for decision-making (Sun 2012: 51). A decision to detain might also be influenced by the capacity to detain, that is, whether a shoujiao facility has been established within the local jurisdiction. Dui Hua reported in September 2014 that the MPS, in a response to a request for information about shoujiao, stated that there were 116 shoujiao facilities nationwide, with some provinces having none at all (Dui Hua 4 September 2014). In that case, the lack of facilities (rather than some characteristic of the unlawful conduct itself) will be critical in determining whether a person caught selling or buying sexual services will be subjected to a period of shoujiao.

\section{Critiques of Shoujiao}

The case description and critique in the above section points out the lack of legal guidelines to determine which of the range of possible punishments may be imposed in a particular instance of prostitution. Further, it is evident that procedural rules provide a poor guide in promoting decision-making that is proportional, transparent or accountable. Another set of critiques focuses specifically on shoujiao.

Critiques of shoujiao replicate many of the criticisms levelled previously at laojiao (Biddulph 2012). Abolition of RETL took so long that there was ample time for a wide range of fundamental legal issues relating to that power to be debated in public, including: fundamental requirements for legality in administrative action, what is required for legal conformity with international human rights and justice principles, fundamental principles of substantive and procedural justice, the appropriate institutional form of powers and the manner of their exercise, as well as institutional structures for supervision of the exercise of administrative decision-making powers and accountability for that exercise. However, when laojiao was abolished, it was done without engaging with these broader debates. The NPC Standing Committee's Resolution on Abolishing Laws and Regulations on Re-education through Labour merely rescinded the documents previously considered to constitute the legal basis of laojiao, stating the conclusion but not the reasoning behind it. As a consequence, the same legal arguments are again being rehearsed in relation to shoujiao. Calls have been made to stop using shoujiao. One critical voice is that of Yu Mingyong, delegate of the Guangzhou People's Consultative Congress and Chief Judge of the Guangzhou Intermediate People's Court, who in 2014 advocated that Guangzhou take the lead in stopping the use of shoujiao (Wu 19 February 2014). People who think like Chief Judge Yu on this matter ask whether it is appropriate to detain sex workers and their clients for up to two years, and even whether they should be punished at all. Whilst no official statement has been made about abolition or reform of shoujiao, support for retaining this power is rapidly eroding. It is possible that shoujiao will suffer the same fact as laojiao; reducing imposition of shoujiao until there is ultimately little left to abolish. This section focuses on legal aspects of these contemporary Chinese debates about the fate of this power to punish. Legal debates are critical to the extent that proposals for 
abolition or reform of detention powers all need legal reasons, even if they are not ultimately the primary reasons.

There are six main legal objections to shoujiao, each are discussed below.

It is an Unconstitutional and Unlawful Deprivation of Personal Liberty that does not have the Necessary Legal Basis.

Is the current regulatory basis of shoujiao an unconstitutional deprivation of liberty? Specifically does it comply with the requirements of the Legislation Law, which requires at Article 8(5) that any power to deprive a person of their liberty must be authorised by law (falü 法律)(Sun 2012: 49-50).

A 'law' (法律) is defined in Article 7 of the Legislation Law to be one passed by either the NPC or its Standing Committee. The Legislation Law goes on to specify the procedures for drafting and passing a law (Chapter 2 Section 2 in respect of laws passed by the NPC, and Chapter 2 Section 3 in respect of laws passed by the NPC Standing Committee). For a legislative instrument to constitute a 'law' as defined in the Legislation Law, it must thus be passed by a designated body (NPC or its Standing Committee) in accordance with the prescribed procedures. The legal prescription that powers to deprive a person of their liberty must be authorised by law in turn raises two questions. The first is about the nature of the legal instrument authorising shoujiao. Is it a 'law'? The second, if a law can be identified, is whether the law adequately describes the power. Is it so vague and formalistic that it fails to define shoujiao in a way that complies with the intent of the Legislation Law?

\section{Legal Basis of Shoujiao}

Is the 1991 Standing Committee Decision a 'law'? At the time this decision was issued, it was generally accepted to be a law as it was issued by the NPC Standing Committee, a body authorised in the Constitution to pass laws. However, the Legislation Law imposed an additional requirement that laws be passed in accordance with prescribed procedures. This requirement casts doubt about the proper characterisation of the class of document issued by the Standing Committee entitled 'Decision', of which there are many. The characteristic of a Decision is that it is often passed quickly, without extensive discussion, in order to give effect to an urgent policy demand, such as to facilitate implementation of a hard strike campaign. Decisions were passed to implement the 1983 Hard Strike campaign against serious crime, the crackdown on Falungong and other 'heretical cults', the Six Evils campaign against prostitution, illicit drugs, amongst others and other 'evils'. None of these documents was passed according to the procedures specified in the Legislation Law, supporting a conclusion that the 1991 Standing Committee Decision is not a 'law'. However, it is not clear that the Legislation Law can operate retrospectively to deprive Decisions such as this the status of law (and thus removing the legal basis for shoujiao).

Another argument about the legality of shoujiao is based on the PSAPL. Some argue that the PSAPL acts as a code in relation to the punishment of sex workers and their clients. If 
so, it would prevail over the 1991 Standing Committee Decision on the grounds that a subsequent law prevails over an earlier inconsistent law. The PSAPL would also prevail over the 2011 State Council Measures as it is of a higher status in the legislative hierarchy (as a law, as opposed to an administrative regulation). The difficulty with this argument is that the PSAPL itself does not explicitly mention, and so does not expressly authorise, either shoujiao or laojiao. If the PSAPL does in fact act as a code, then its silence on shoujiao should be interpreted as negating the legality of shoujiao. At least its silence demonstrates that the PSAPL does not authorise shoujiao (Sun 2012: 49).

\section{Impermissible Delegation?}

The Legislation Law Article 9 prohibits delegation of law-making power to the State Council with respect inter alia to powers to deprive a person of their liberty. As discussed above, the scope of this power is defined in the 1991 Standing Committee Decision as 'those who prostitute or who use prostitutes'. Arguably this reference does not constitute a definition as much as it sets out an idea. The idea sketched out in the 1991 Standing Committee Decision is given some more concrete form in the 2011 State Council Measures. Here the definition of targets at Article 7 provides that 'apart from punishment under PSAPL Article 66, sex workers and their clients whose conduct is insufficient to warrant laojiao may be punished with shoujiao'. It goes on to exempt sex workers under 14 years old, those who are pregnant or nursing a child under one year old, those with a serious infectious disease that is not a sexually transmitted infection, and people who have been kidnapped and sold into prostitution. The fact that the legal detail required to exercise the power of shoujiao is contained in an administrative regulation issued by the State Council, rather than in an instrument issued by the NPC Standing Committee, offends against the prohibition in the Legislation Law on delegating power to make rules for deprivation of personal liberty.

Inadequate Definition of the Offence and Standards of Evidence Required to Prove It The proscribed conduct, prostitution, and the evidence required to prove it, remains undefined in the legal documents that authorise its punishment. The 2011 State Council Measures themselves are completely unequal to the task of defining who, and what conduct, fall within the scope of shoujiao. Neither the 1991 Standing Committee Decision, nor the 2011 State Council Measures contain a definition of conduct that constitutes prostitution and make no mention of the types of evidence necessary to prove a prostitution transaction has taken place. These definitions are left to an array of documents and explanations issued by the MPS and to local policing practices.. ${ }^{11}$

\section{There is a Lack of Proportionality}

Imposing a period of detention for up to two years and the restrictive conditions to which a person is subject whilst in detention are both disproportionately harsh. This is particularly so given that the sanctioned conduct is considered not to be sufficiently serious to warrant criminal prosecution and imposition of a criminal sanction (Sun 2012: 50). This complaint about the 
disproportionately heavy punishment imposed under shoujiao is particularly acute now that a large proportion of minor criminal offences are punished by imposition of a non-custodial term of community correction.

Viewed from the perspective of the person being detained, deprivation of liberty for between six months and two years is no less (and is even more) a punishment than a period of detention for 15 days. From that point of view, the legal distinction between a 'punishment', a 'coercive measure' and a 'handling measure' is nonsensical. It is not hard to understand how law suffers a legitimacy deficit when the legal treatment of a power such as shoujiao becomes radically divorced from perception of its reality by those subject to it.

The Unequal Treatment of Similarly Situated People Breaches the Constitutional Principle of Equality Before the Law (at Article 33)

As the case of Huang Haibo demonstrates, the public security agencies are empowered to and do impose different punishments for the same conduct. In the case of Huang Haibo, a fine was not imposed but two consecutive periods of detention were. In other cases a fine is imposed. In addition, it is not uncommon for different punishments to be imposed on the sex worker and the client, with the sex worker placed in detention and their clients fined (Sun 2012: 51).

\section{The Lawful Scope of Discretion is too Broad}

The section above discusses the broad discretion exercised by the police to select between different powers to impose a sanction. That broad discretion also exists within shoujiao itself. Both the 2011 State Council Measures Article 9 and the 1991 Standing Committee Decision specify that the time limit for detention is between six months and two years, but fail to state the types of considerations to be taken into account in determining the amount of time to be imposed within those two outer limits. The 2012 MPS Regulations provide that the standard to be applied in a determination to impose handling measures such as: shoujiao, an order for giving up drugs in the community, detention for drug detoxification under compulsory quarantine for drug rehabilitation (CQDR), or detention of juveniles in a re-education camp, is 'where it is necessary' (Article 147(4)). This provision provides no guidance at all as to the appropriate sanction to impose. The fact is that the almost entire lack of legal definition of the targets of this form of 'compulsory education measure' allows the police an almost unconstrained discretion as to the penalty they might impose.

\section{Decision-making Lacks Transparency and is Procedurally Unfair}

In debates about laojiao, a widely held consensus was that the International Covenant on Civil and Political Rights Article 9 requires that a decision to deprive a person of their liberty be made by a court (Biddulph 2012). Similar arguments are made in respect of shoujiao, especially amongst those calling for its abolition who point out that decision-making and enforcement power is concentrated in the hands of the police (Sun 2012: 51; Wu 19 February 2014). However, the debate about procedural fairness is broader than the question of the appropriate decision- 
maker. It also extends to the types of procedures that must be followed in determining whether to impose a punishment and questions of transparency in decision-making.

One of the criticisms of laojiao was that a person may not know they had been sent to a term of laojiao until after the decision was made and they were delivered to the laojiao camp. In 2002 MPS responded to some of the criticisms about arbitrariness in decision-making in the Regulations on Public Security Organs Handling Re-education through Labour Cases by requiring that a person who may be subject to laojiao be interviewed as part of the process of verification of the evidence used to base the decision prior to a decision being made (Article 17). These regulations also introduced a form of internal administrative hearing (lingxun 领讯) that enabled a person to be presented with evidence and to have a chance to be represented and heard prior to the decision being made. In 2005 the MPS issued the Opinion on Further Strengthening and Improving the Work of Examination and Approval of Re-education through Labour (Guanyu Jinyibu Jiaqiang he Gaijin Laodong Jiaoyang Shenpi de Shishi Yijian . 关于进一步加强和改进 劳动教养审批工作的实施意见) which strengthened procedural rules and expanded the scope of the internal hearing procedure. But, whilst the same criticisms of lack of procedural fairness can be levelled at shoujiao, no similar provision for a hearing or hearing-type procedure has been made available.

\section{Modes of Justice: Institutionalisation and Values}

Populist and Formal Modes of Justice

In the Maoist era, populist forms of justice were associated with some of the worst forms of mob violence and unrestrained abuse of the targets of this violence. So-called mass-line justice saw the dismantling of formal judicial infrastructure and justice being wielded directly by the people. Of course, this was not a form of spontaneous justice that directly gave effect to popular sentiment, but was orchestrated by the party with the purpose of achieving revolutionary transformation of society. Public-shaming spectacles, public sentencing rallies in the criminal justice arena, and hard strike campaign-style law enforcement have all been closely associated with populist modes of justice. Embrace of formal modes of justice in the reform era saw the re-establishment, strengthening and increasing professionalisation of the judicial organs of state (the police, procuratorate and courts) including the reinstatement of public trials and a commitment to establishing a stable legal order (Leng 1982: 205).

However, bureaucratisation and institutionalisation of the administration of justice has not seen the complete eradication of the techniques of populist forms of justice: rhetorical commitment to the mass line and continuing use of campaign-style enforcement, including public shaming (in this case, of sex workers). Scholars have noted the resurgence from the mid-2000s of some of these populist forms of justice in the embrace of informal modes of dispute resolution, including mediation, at the expense of more formal judicial dispute-resolution processes (Minzner 2011; Liebman 2011). Public humiliation of those targeted for punishment persists. In 2015 it has taken the form of televised 'confessions' of lawyers detained and charged with (but not convicted of) criminal offences for defending their clients in so-called 'sensitive cases' (Yu 19 July 2015). 
But these populist forms of justice differ from those of the revolutionary era in a number of respects. As Michael Dutton has argued, campaigns are now technical and pragmatic tools of social control rather than political tools for revolutionary transformation of society (Dutton 1992: 218-19; Dutton 1995: 418-21). Elaine Jeffreys has also argued that in the reform-era campaigns, mass shaming and sentencing rallies are not the same as those of the Maoist era as they are operate with reference to law (even if the conduct itself is unconstitutional or unlawful) rather than being antithetical to law. They are now merely punitive, rather than seeking in addition to have some ideologically transformative role. In this way we can see that formal and bureaucratic modes of justice have accommodated rather than displaced some techniques of popular justice. An analysis of justice in terms of populist and formalist modes of justice focuses our attention on the degree and qualities of institutionalisation of the administration of justice. In relation to prostitution it raises questions about the extent to which, and the ways in which, law institutionalises processes for policing and sanctioning prostitution, and the impact of campaign-style enforcement against prostitution.

\section{Institutionalization of Processes for Policing and Sanctioning Prostitution}

The discussion above of the rules relating to policing and punishment of prostitution reveals an incomplete process of legalisation of these powers. In particular the legal definition of the detention power of shoujiao remains vague and, as discussed above, remote from the demands of the contemporary legal system. It might be easy to characterise the legal regulation of shoujiao as a vestige of an earlier, more politicised approach to regulation, as a type of historical remnant. However, the State Council's amendment of the Measures for Detention for Education of Prostitutes and Clients of Prostitutes in 2011 casts doubt on such a conclusion. The amendment is a contemporary restatement of the scope and procedures for imposing this form of detention and continues to lack detailed prescription of either the standards or procedures for imposing shoujiao.

Reforms made shortly before abolition of laojiao to institute an internal hearing procedure and even to consider whether to transfer decision-making power to the courts reveal sensitivity to the pernicious effects of concentration of power in the hands of the police. In the area of sanctioning prostitution, power is even more concentrated than it was for laojiao. The public security agencies determine which punishment to impose, the severity of the fine and length of detention; they operate the detention centres and hear appeals against decision-making under administrative review. The only external oversight agency is the people's courts, which may hear challenges to the lawfulness of a police decision. The lack of clear legal standards to determine what conduct constitutes prostitution, what constitutes severe or minor circumstances, and to guide sentencing, significantly reduces the capacity of the court to carry out a robust examination of these decisions. 


\section{The Impacts of Campaign-style Enforcement}

Campaign-style enforcement has continued. In the area of criminal justice it has taken the form of hard strikes against serious crime (these campaigns have been extensively explored in Trevaskes (2-2; 2003a; 2003b; 2004; 2007a; 2007b). Even though the criminal justice policy of 'Balancing Leniency and Severity' was seen as a move away from the ethos of the severely punitive approach to crime embodied in the hard strike, it has not seen the end of hard strikes or campaign-style enforcement. ${ }^{12}$. The periodic use of campaign-style enforcement against vice, marked by concerted enforcement and severe punishment, demonstrates the will of the party-state to exercise direct physical and moral dominance of the social sphere. In Scot Tanner's (2000) words, law and order hard strike campaigns are intended to re-establish the 'balance of awe' over both criminals and society at large. A similar judgment can be made in respect of anti-vice campaigns; which in addition seek to reestablish dominance over moral as well as coercive spheres.

In the reform era, hard strike campaigns have been waged periodically against prostitution, which has been labelled one of the Six Evils (liu da xie'e 六大邪恶) (alongside gambling, pornography, illicit-drug use, and kidnapping and selling women and children). These campaigns may be waged nationally, such as the 1989 Six Evils Campaign (Biddulph 2007) and the 2010 Hard Strike Rectification Campaign (yanda zhengzhi xingdong 严打整治 行动) (People's Daily Online 22 June 2010), or locally, such as the two clean-ups carried out in Beijing in April and May 2012 (Human Rights Watch 2013: 3) and the crackdown waged in February 2014, discussed above. Public humiliation of sex workers also continues as part of these clean-up campaigns with the aim of educating and warning the public. This type of expressive punishment that features during campaigns also demonstrates the pernicious influence of campaign-style enforcement (yundongshe zhifa 运动式执法) on enforcement practice and upon respect for fundamental principles of individual dignity.

Campaigns certainly substantively undermine fair treatment of people who have not yet been found guilty of an administrative infringement, much less a criminal offence. Campaign-style enforcement has harmful impacts on public health and physical safety of sex workers. It drives sex workers into underground venues where they are more at risk of harm and exploitation. Campaigns discourage safe sexual practices, including the use of condoms, and regular testing and treatment for STIs and HIV (Human Rights Watch 2013: 3). Both proprietors of brothels and sex workers themselves are reluctant for sex workers to carry condoms, as possession can be used by the police as evidence of prostitution and form the evidentiary basis for punishment.

The rules governing sanctioning of prostitution, discussed above, thus make space for the coexistence of populist and formalist approaches to justice. Concentration of power in the hands of the police to determine the appropriate sanction, coupled with their responsibility to implement campaigns, ensures the exercise of police discretion is shaped by the politics of campaigns. The system of punishments as it is currently constructed in law lacks institutional safeguards or impediments to the unconstrained exercise of this discretion. 


\section{State-centred Governance and People-oriented Governance}

The second axis upon which justice is examined in this chapter is the move to people-oriented governance away from state-oriented governance. This axis focuses attention on the values reflected in the law. Values, of course, are not only stated in legal and policy documents but are also reflected in institutional arrangements of power and enforcement practice. So a discussion of values cannot be completely separated from the institutional arrangements established by the law or enforcement practice (discussed above). The analysis in this section seeks to distil the values reflected both in the text of the law and in the way it institutionalises power.

The Third Plenary Session of the Sixteenth Central Committee meeting in October 2003 resolved to adopt 'people-oriented governance' and decided to amend the Constitution to include recognition and protection of human rights. ${ }^{13}$. This amendment was enacted in March 2004, by adding a provision to Article 33 that, 'The State respects and protects human rights'. For legal academics, the embrace of 'people-oriented governance' and the inclusion of a Constitutional guarantee to protect and respect human rights marked a significant departure in thinking about punishments. In the criminal justice sphere, people-oriented governance has been interpreted as requiring a number of changes in priorities. Whereas state-oriented governance privileges the interests of state agencies in punishing crime and preserving social order, people-oriented governance requires that priority be given to protecting the rights of the individual offender as long as social and national interests are not endangered (Qu 2005: 21-2). Some call for reform of criminal trial procedure to better protect human rights (Xie and Jian 2007). Others argue that the state now has an obligation stemming from both domestic and international law not to infringe upon individual human rights (Guo 2009; Wu 2008).

After an apparent setback for law-based governance in the closing years for the HuWen administration under the direction of Zhou Yongkang, much has been made of the renewed emphasis by Xi Jinping on rule of law and the need for governance to be based on and constrained by law (his much quoted governance within a 'cage of regulations'). The decision of the Eighteenth Central Committee at its Third Plenary Session in December 2013 (Decision on Several Important Questions on Comprehensively Deepening Reform) included a resolution to abolish laojiao, and 'to perfect the system of laws for punishment and correction of unlawful and criminal acts, and to complete the system of community corrections'. This decision initially suggested that the party-state may be willing to consider reforms in the sanctioning system more closely aligned with human-rights considerations. The latest statement of the official line, the 'Four Comprehensives' (sige quanmian 四个全面) adopted at the NPC meeting in March 2015 reaffirms a commitment to the role of law in governance. ${ }^{14}$.

Some recent reforms in the sanctioning system have been identified as animated by a people-oriented, humanist approach to governance. Abolition of laojiao is one. In the area of criminal justice, the policy of Balancing Leniency and Severity is another. Reforms to the Criminal Law (2011) and Criminal Procedure Law (2012) to implement this policy include 
elements of mass-line, people-oriented pragmatism, as well as human rights sensibilities. Illustrations are the emphasis on lenient handling, education and the use of non-custodial punishments where possible for juvenile offenders (Qin 2014), and increasing use of noncustodial sanctions for dealing with minor offenders (such as community correction) (Wu 2008: 48). Another such reform is use of criminal reconciliation where the perpetrator pays compensation and obtains the forgiveness of the victim in return for lenient sentencing. Such a system also reflects mass-line sentiment in that it seeks to resolve the conflict between perpetrator and victim, enabling the court to impose a sentence that both parties will accept. It is focused on obtaining an acceptable outcome. It is also animated by the (to my mind tendentious) theory that criminal reconciliation protects 'rights' as it combines protection of the rights of the victim, offender, and of society at large, which has an interest in restoring social harmony (Zi 2014).

But, it would be a mistake to align people-oriented governance too closely or exclusively with values of protection of human rights. As the examples above and subsequent proclamations in the name of people-oriented governance make clear, people-oriented governance also encompasses a healthy commitment to populist, mass-line strategies that privilege pragmatic, outcome-driven processes over general application of legal principles, and that align the party with the 'people's feelings'. Mao declared that the mass-line emphasised the close relationship between the party and the people and its responsiveness to their needs and views. In $2002 \mathrm{Hu}$ Jintao articulated the principles that 'power be used for the benefit of the people, and that the party should exercise power in a way that cares for the people by empathizing with their feelings' (quan wei min suoyong, qing wei min suoxi 权 为民所用, 情为民所系). ${ }^{15}$. This particularistic interpretation of people-oriented governance (aligning the administration of justice with the people's feelings) was reiterated in Xi Jinping's explanation of 'comprehensive development of rule of law'. In it we find the catch-cry to 'let the people (masses) perceive fairness and justice in each judicial case' (rang renmin qunzhong zai mei yige sifa anjian zhong dou ganshou dao gongping zhengyi 让人民群众在每一个司法 案件中都感受到公平正义) (People's Daily Online 11 May 2015). One of the interpretations of people-oriented governance is the requirement that adjudication and enforcement take account of public sentiment. Of course public sentiment is not singular. It is also malleable and subject to the influence of party education and propaganda work which is undertaken as part of the party's perceived responsibility to shape and lead public morality (Bakken 2004; 2008).

This approach may be contrasted with a more abstract notion of justice that looks to application of legal principles to resolve disputes rather than looking to the acceptability of the outcome of cases to the parties involved. The perceived failure of the formal adjudication processes to provide a final resolution to disputes enabled the turn toward use of more particularistic forms of dispute resolution (Fu and Cullen 2011). Valorisation of the Ma Xiwu style of mediation is illustrative as it emphasises mass-line elements of mediation that are responsive primarily to popular sentiment rather than to legal principle. The aim of this style 
of mediation is to reach a resolution that people will accept and that displays a willingness to ignore the parameters of the formal legal system to do this (Minzner 2011).

At its Fourth Plenum in 2014, the Central Committee articulated its policy of 'building a socialist rule of law system with Chinese characteristics' in its Decision on Some Major Questions in Comprehensively Promoting Governing the Country According to Law. This decision also intimated another important component of people-oriented governance, a moral component. In this decision we were given a hint that strengthening governance is not considered to be purely a technical exercise, but is integrally bound to the role of the party as the leader of the moral life of the nation. This decision located the party as the leader and guardian of core values and social morals in the following terms:

State and social governance require that both law and virtue play a role together. We must persist in grasping the rule of law with one hand, and the rule of virtue with the other hand, to forcefully carry forward the Socialist core value system, carry forward China's traditional virtue, and foster social morals, professional ethics and household virtues. ${ }^{16}$

Such a formulation repeats the prescription by Jiang Zemin in 2002 that governance requires a combination of rule by virtue and rule by law. ${ }^{17}$.

When we consider the legal values brought to bear in policing prostitution, a focus on people-oriented and state-oriented governance helps us to identify the values reflected in the form of law, including the degree to which it enhances flexibility in enforcement practices and its weaknesses in instituting protections for those targeted for punishment. But the concept of people-oriented governance itself is ambivalent when it comes to protecting the rights of the accused. As people-oriented governance has also been used to represent the party-state's responsiveness to public sentiment, it may not favour protection of the rights of offenders at all. In terms of prostitution, privileging of public sentiment and morality in the name of people-oriented governance is at odds with the alternative vision of people-oriented governance that would call for better protection of the rights of sex workers and their clients. Elements of State-oriented Regulation: Legal Text and Enforcement Practice

The fragmented legal regulatory framework governing powers to sanction prostitution in many important respects remains oriented toward facilitating the convenience of enforcement as opposed to protecting individuals who are the subject of enforcement. Of central importance is the concentration of decision-making and enforcement powers in the hands of the public security agencies. The sanctions imposed under both the PSAPL and shoujiao are determined by the police, and people are detained in detention centres operated by the police. Rules do not create a clear distinction between conduct that is to be punished by fine or a short period of detention (five days or between 10 and 15 days) and the conduct that is to be punished by longer periods of detention (between six months and two years). Nor do they set out standards to guide the length of punishment to be imposed within either of these overlapping powers.

Legal elasticity was the favoured form of Leninist legal instrumentalism as it enabled flexibility in social control and in suppressing class enemies (Berman 1963: 32 [discussing the 
Soviet Union]; Keith and Lin 2001: 41). The lacunae in the formal regulatory regime traced in the discussion above privileges legal elasticity over a more rigid schema to protect targeted individuals, which allows for flexible punishment of prostitution in accordance with the dictates of campaigns and the periodic moral panics that initiate them. Today, legal elasticity facilitates police responsiveness to periodic party directives to deal with social order challenges and to implement campaigns.

A preference for state-oriented governance also limits the procedural and substantive fetters on the exercise of powers such as shoujiao, which a differently organised set of legal rules might better protect. Since introduction of mandatory procedural rules in 1996 with passage of the Administrative Punishments Law, aspects of police enforcement practice have been subject to more detailed and onerous requirements, whose aim at least is to constrain the ways the police exercise their powers and to protect targeted individuals. The 2012 MPS Regulations reflect the requirements of these legislative instruments and define better the procedures in handling administrative cases in the name of the values of openness, proportionality, timeliness and fairness (discussed above). However, the efficacy of these rules to improve protection of the targeted individual is undermined by poor legal definition of core concepts; this includes what conduct constitutes prostitution, which evidence may be used and the standard of proof required.

The protections that might stem from strengthened mandatory procedural requirements are also undermined by lack of any effective way to hold police decision-making accountable for breach of them. Administrative litigation and review, that is, the ways in which an aggrieved citizen might complain about failure to observe procedural rules, remains poorly utilised. Although courts may determine a police decision is unlawful for breaching mandatory procedural rules, in practice they are reluctant to do so without also finding that the substantive decision was unlawful too. In a situation where the substantive scope of lawful decision-making is so broad, reliance solely on an argument about procedural unlawfulness is unlikely to succeed in administrative litigation. The continuing failure of systems of complaint-driven accountability, involving administrative litigation and administrative review, to act as a real constraint on police decision-making, limits the capacity of these rules to chasten police excesses.

\section{Elements of People-oriented Regulation: Legal Text and Enforcement Practice}

Specification of mandatory procedural requirements in both the PSAPL and the 2012 MPS Regulations has been identified as marking great progress in the legal protection of the human rights of offenders. Some observers have even gone so far to claim that the (2006 version of the) PSAPL reflected the 'old English principle of natural justice, that all powers must be exercised in a just manner' (Feng 2005: 286). The discussion of enforcement practice in this chapter suggests that such a conclusion may be a little optimistic. But it does highlight inconsistencies in developments in the law. Public humiliation of sex workers, coupled with the continuing reliance on campaign-style enforcement (specialist struggles, rectifications etc.), exist in clear tension with one interpretation of people-oriented governance, that is, the 
protection of human rights. Continuing attachment to the public humiliation of sex workers, public sentencing rallies, and public parading of criminal convicts, persists in direct conflict with China's international human-rights commitments. ${ }^{18}$. It also brings China's version of rule of law into tension with the understanding of rule of law at the level of the United Nations, which defines the concept of rule of law to be 'consistent with international human rights norms and standards'. 19

But these spectacles also represent a very public demonstration of the party's moral stance in its disapproval of prostitution, that is, the more populist meaning of people-oriented governance. The official judgment that prostitution is the 'hideous conduct that damages social morals' (youshang shehui fenghua de choue xingwei 有伤社会风化的丑恶行为) constitutes the harm that forms the basis upon which prostitution is rendered unlawful and upon which sex workers and their clients are punished (Chen 2013: 291). Such a judgment hides a more complex view of the nature of the 'problem' and appropriate regulatory responses. As Elaine Jeffreys points out, the social harm caused by prostitution, the increasing significance of public health considerations, and the most appropriate approaches to regulating prostitution, are all the subject of ongoing debate (Jeffreys 2012a). The incoherence of the law in terms of values it both reflects and enacts might thus be understood as accurately reflecting the conflicts in (official) attitudes toward rights-oriented visions of the rule of law, prostitution and the principles of justice that apply to the morally marginalised.

\section{Conclusion: Visions of (In)justice}

If we return finally to the ways in which text and the spectacle together tell us something about the concept of justice as it relates to punishment of prostitution, we can see that the law and the ways in which law institutionalises power to sanction prostitution reflect concepts that are in fundamental tension with each other. Persistent use of campaigns and public shaming reflects prioritisation of pragmatism and legal flexibility at the expense of principles of equality before the law, proportionality and procedural justice.

After abolition of laojiao, scholars have taken up the task of perfecting and reforming the system of punishments. Shoujiao has featured prominently amongst the powers that have been discussed. As the analysis above demonstrates, there is any number of legal problems with this power.

Any reforms of the current system for policing and punishment of prostitution must negotiate two sets of precepts: 'perfecting the system of punishments', and party leadership in 'fostering social morals' and 'traditional virtue'. Official endorsement of a humanist (rendao zhuyi 人道主义), rights-oriented approach to governance continues. However, in sanctioning prostitution, the administration of justice has been primarily oriented toward the partystate's leadership of social morality and to enforcement convenience, rather than a commitment to abstract notions of human rights. But, at the practical level, the internal contradictions in the visions of justice discussed in this chapter also create a space to allow the demise of powers such as shoujiao in the name of rule of law, in the same way that reeducation through labour was allowed to wither before it was finally abolished. 


\begin{abstract}
${ }^{1}$ This research was supported by a grant from the Australian Research Council [FT130100412]
${ }^{2}$ Throughout, I have used the term sex worker except where the term is directly translated from Chinese. The term maiyin (卖淫) should be translated as prostitution or prostitute rather than sex worker.

${ }^{3}$ Debased (yue) status class was a legal category that included prostitutes, actors and musicians and was distinguished from commoner households (Sommer 2000: 230-1). It was 'a form of hereditary penal servitude or slavery to the imperial state" (Sommer 2000: 7).

4 'Report on Striking Hard Against and Resolutely Suppressing Prostitution and Preventing the Spread of Sexually Transmitted Diseases' submitted to the Chinese People's Political Consultative Conference (CCPCC) and the State Council by the MPS, MoJ, Ministry of Health, Civil Administration and Women's Federation on 21 September 1987.

${ }^{5}$ Detailed regulations, to the extent they exist, are provided at the local level, for example in the Regulations of Guizhou Province on Prohibition of Prostitution and Using Prostitutes (贵州省禁止卖淫嫖娼的规定) passed initially on 23 November 1988.

${ }^{6}$ They are reproduced at http://www.360doc.com/content/14/0531/17/97556 382556234.shtml

${ }^{7}$ In the MPS issued an interpretation of Article 128 of the Criminal Procedure Law, MPS Regulations on the Procedures for Handling Criminal Cases passed on 20 April 1998 to come into effect on 14 May 1998. At Article 112 of those regulations it provided that the time limits for the 'investigation and detention period' (zhencha jiya qixian 侦查羁押期限) not to commence until clarification of the name, address and background of the detainee, as providing that the time limit for calculating the period of detention (juliu 拘留) should not commence until the name and address of the detainee was clarified. This interpretation expanded the amount of time for which a person could be detained prior to arrest, which was clearly not the intention of the law.
\end{abstract} See Wang (2000: 93-5).

${ }^{8}$ Article 113: In handling cases of public security, public security organs and the people's police are forbidden to beat, abuse, mistreat or humiliate the persons who commit acts against the administration of public security.

${ }^{9}$ Article 45 , with a possible extension of up to 24 hours where the situation is complex, and another possible extension of up to 48 hours where the person does not tell their true name and address. A person is not to be questioned for continuous 12 -hour periods or restrained during questioning.

${ }^{10}$ What conduct constitutes prostitution is not defined in legislation and depends upon factors set out in a range of normative documents, leading to inconsistent approaches throughout the country and across time. See discussion in Biddulph (2007).

${ }^{11}$ To the extent a national definition of prostitution exists, it is set out in the MPS Response to a Request for Instructions on the Question of How to Determine the Nature of and Deal with Sexual Acts between People of the Same Sex with Money and Property as the Intermediary, 28 December 2001 (Gong'an Bu Guanyu Dui Tongxing Zhijian Yi Qiancai Wei Meijie de Xing Xingwei Dingxing Chuli Wenti de Pifu 公安部关于对同性之间以 钱财为媒介的性行为定性处理问题的批复). This document provides that prostitution should be understood to include: 'inappropriate sexual acts between non-specified people of different or the same sex with money or property as the intermediary, including oral sex or masturbation.' The definition of prostitution is discussed further in Biddulph (2007: 167-172).

${ }^{12}$ Such as the People's War on Drugs, discussed in Trevaskes (2007b; 2010).

13 "Zhongguo gongchandang dishiliujie zhongyang weiyuanhui disanci quanti huiyi gongbao"

(Communique of the Third Plenary Session of the Sixteenth Central Committee of the Chinese Communist Party), Xinhua News Agency, 14 October 2003, http://www.people.com.cn/GB/shizheng/1024/2133923.html ${ }^{14}$ The four comprehensives are as follows: to comprehensively build a moderately prosperous society, to comprehensively deepen reform, to comprehensively govern the country according to the law, and to comprehensively apply strictness in governing the Party.

${ }^{15}$ In a speech given by Hu Jintao at Xibaipo soon after he became President in 2002. The speech was reproduced by Xinhua at http://news.xinhuanet.com/ziliao/2003-01/02/content 731349.htm

${ }^{16}$ CCP Central Committee Decision concerning Some Major Questions in Comprehensively Moving Governing the Country According to the Law, 23 October 2014. Translation from the China Copyright and Media web at https://chinacopyrightandmedia.wordpress.com/2014/10/28/ccp-central-committee-decision-concerningsome-major-questions-in-comprehensively-moving-governing-the-country-according-to-the-law-forward/

${ }^{17}$ See Jiang (12 November 2002, at Part IV point 3): 'Promote ideological and ethical progress. Ruling the country by law and ruling the country by virtue complement each other. It is necessary to establish a socialist 
ideological and ethical system compatible with the socialist market economy and the socialist legal standard and consistent with the traditional virtues of the Chinese nation'.

${ }^{18}$ China's obligations arise under a range of international human rights instruments including the Universal

Declaration of Human Rights, which prohibits torture and inhuman and degrading punishment; the Convention Against Torture and Other Cruel, Inhuman or Degrading Treatment or Punishment; the International Covenant on Civil and Political Rights; and the UN Body of Principles for the Protection of All Persons under Any Form of Detention or Imprisonment 1988.

${ }^{19}$ The UN defines rule of law as 'a principle of governance in which all persons, institutions and entities, public and private, including the State itself, are accountable to laws that are publicly promulgated, equally enforced and independently adjudicated, and which are consistent with international human rights norms and standards. It requires, as well, measures to ensure adherence to the principles of supremacy of law, equality before the law, accountability to the law, fairness in the application of the law, separation of powers, participation in decision-making, legal certainty, avoidance of arbitrariness, and procedural and legal transparency' (Report of the Secretary-General: The rule of law and transitional justice in conflict and postconflict societies, 2004).

\section{References}

Bakken, B. 2004. Moral Panics, crime rates and harsh punishment in China. The Australian and New Zealand Journal of Criminology, 37 (Supplement):67-89.

Bakken, B. 2008. The culture of revenge and the power of politics: a comparative attempt to explain the punitive. Journal of Power, 1 (2):169-187.

Berman, H. J. 1963. Justice in the U.S.S.R. An Interpretation of Soviet Law, Revised ed. Cambridge: Harvard University Press.

Biddulph, S. 2007. Legal reform and Administrative Detention Powers in China, Cambridge: Cambridge University Press.

Biddulph, S. 2012. Between rhetoric and reality: the use of international human rights norms in law reform debates in China. In J. Gillespie \& P. Nicholson eds., Narrative and Legal Transfers: Informing Law and Development, Cambridge: Cambridge University Press, pp. 143-178.

Boittin, M. 2013. New perspectives from the oldest profession: abuse and the legal consciousness of sex workers in China. Law \& Society Review, 47(2), 245-278.

Brady, J. 1981. The transformation of justice under socialism: the contrasting experiences of Cuba and China. The Insurgent Socialist, X (4), 5-24.

Brady, J. 1982. Justice and Politics in People's China: Legal Order or Continuing Revolution? London: Academic Press.

Chen, P. 2013. Maiyin piaochang xingwei ji qi chufa de fali yanjiu (Jurisprudential research on the punishment of prostitution). Fazhi yu Shehui (Legal System and Society), 12, 291-295.

Cohen, J. 1966. The Criminal process in the people's republic of China: an introduction. Harvard Law Review, 79(3), 469-533. 
Dui Hua. 2014. MPS: China has 116 custody and education centers. Human Rights Journal, 4 September. Available from: $h$ ttp://www.duihuahrjournal.org/2014/09/mps-china-has-116custody-and-education.html [12 August 2015]

Dui Hua. Translation: 'Perp Walks' for Petty Thieves Should Cease. 29 July 2010. Available from: www.duihuahrjournal.org/2010/07/translation-perp-walks-for-petty.html [12 August 2015]

Dutton, M. 1992. A Mass line without politics, community policing and economic reform. In A. Watson ed., Economic Reform and Social Change in China, London: Routledge, pp 200227.

Dutton, M. 1995. Dreaming of better times: 'repetition with a difference' and community policing in China. Positions: East Asia Cultures Critique, 3(2), 418-447.

Feng, Suozhu, ed. 2005. Zhonghua Renmin Gongheguo Zhi'an Guanli Chufa Fa Shiyi yu Shiyong Zhinan (Guide to the Interpretation and Practice of the PRC Security Administrative Punishments Law). Beijing: Zhongguo Renmin Gong'an Daxue Chubanshe (China People's Public Security Press).

Fu, Hualing, and Choy, D.W. 2009. Administrative detention of prostitutes: the legal aspects. In J. Tucker, D. L Poston Jr., Ren, Qiang, Gu, Baochang, Zheng, Xiaoying, S. Wang and C. Russell eds., Gender Policy and HIV in China: Catalyzing Policy Change. New York: Springer, pp. 189-199.

Fu, Hualing, and Cullen, R. 2011. From mediatory to adjudicatory justice: the limits of civil justice reform in China. In M. Woo and M. Gallagher eds., Chinese Justice: Civil Dispute Resolution in Contemporary China, Cambridge, New York: Cambridge University Press, pp. 25-57.

Gillet, K. 2010. China: End to shame parades of sex workers a step forward- activists. Global Issues, 6 August. Available from: http://www.globalissues.org/news/2010/08/06/6530 [12 August 2015]

Guo, Daohui. 2009. Renquan de guojia baozhang yiwu (State Responsibility for Human Rights Protection). Hebei Faxue (Hebei Law Science), 27(8), 10-17.

Herschatter, G. 1997. Dangerous Pleasures: Prostitution and Modernity in Twentieth-Century Shanghai, Berkeley: University of California Press.

Human Rights Watch. 2013. 'Eliminating prostitution' the harm suffered by Chinese sex workers. Human Rights Watch. Available from:

https://www.hrw.org/news/2013/05/14/china-end-violence-against-sex-workers [12 August 2015] 
Jacobs, A. 2010. China pushes to end public shaming. New York Times. 27 July. Available from: http://www.nytimes.com/2010/07/28/world/asia/28china.html?_r=0 [12 August 2015].

Jeffreys, E. 2012a. Prostitution Scandals in China: Policing, Media and Society, Abingdon: RoutledgeCurzon.

Jeffreys, E. 2012b. Prostitution and propaganda in the People's Republic of China. In A-M. Brady ed., China's Thought Managemen, London and New York: Routledge, pp. 146-163.

Jiang, Zemin. 2002. Full text of Jiang Zemin's report at the 16th Party Congress. People's Daily, 12 November. Available from en.people.cn/200211/18/eng20021118_106983.shtml [12 August 2015].

Keith, R. and Lin, Zhiqiu. 2001. Law and Justice in China's Marketplace, New York: Palgrave.

Law Yearbook Editorial Committee, ed. 2015. Falv Nianjian (Law Yearbook of China), Beijing: Press of Law Yearbook of China.

Leng, Shaochuan. 1982. Criminal justice in post-Mao China: some preliminary observations. The Journal of Criminal Law \& Criminology, 73 (1): 204-237.

Leng, Shaochuan, and Hongdah Chiu. 1985. Criminal Justice in Post-Mao China: Analysis and Documents, Albany State: University of New York Press.

Liebman, B. 2011. A Return to populist legality? historical legacies and legal reform. In S. Heilmann and E. Perry eds., Mao's Invisible Hand: The Political Foundations of Adaptive Governance in China, Cambridge and London: Harvard University Asia Centre, pp. 165-200.

Liu, Renwen. 2014. Bao'an chufen yu Zhongguo xingzheng jujin zhidu de gaige (Security Punishments and the Reform of China's Administrative Detention System). Fazhi Yanjiu (Rule of Law Studies), 6, 13-20.

Liu, Wei, Jia, Ping, and Qu, Renzong. 2014. Shourong jiaoyu zhidu dang feizhi (The system of detention for education should be abolished). Caixin online, 9 April. Available from: http://opinion.caixin.com/2014-04-09/100662620_all.html [12 August 2015]

Lubman, S. 1999. Bird in a Cage: Legal Reform in China after Mao, Stanford: Stanford University Press.

Minzner, C. 2011. China's turn against the law. American Journal of Comparative Law, 59, 935-984.

People's Daily Online. 2010. Ministry of Public Security deploys the public security system nationwide to carry out a Hard Strike Rectification Campaign. People's Daily Online, 22 June. Available from: http://politics.people.com.cn/GB/1027/11942109.html [12 August 2015] 
People's Daily Online. 2015. Jianchi gongzheng sifa: rang renmin qunzhong zai mei yige sifa anjian zhong dou ganshou dao gongping zhengyi (Adhere to judicial justice: let the people perceive fairness and justice in each judicial case). People's Daily Online, 11 May. Available from: http://theory.people.com.cn/n/2015/0511/c396001-26981416.html [12 August 2015]

Qin, Jinghua. 2014. Wei chengnian ren fanzui xingshi sifa zhengci de fali fenxi (Legal analysis of juvenile criminal justice policy). Fazhi Bolan (Legality Vision), 12, 221.

Qu, Xuewu. 2005. Qingzui zhi fa jiazhi quxiang yu renshen quanli baohu (Legal value orientation of minor crimes and protection of the right of the person). Hebei Faxue (Hebei Law Science), 23(11), 18-23.

Qu, Xuewu. 1996. Bao'an chufen yu Zhongguo xinfa gaige (Security punishments and China's criminal law reform). Faxue Yanjiu (Chinese Journal of Law), 18(5), 55-68.

Sommer, M. 2000. Sex, Law and Society in Late Imperial China, Stanford: Stanford University Press.

Song, Ying. 2015. Hou laojiao shidai shourong jiaoyu de xingszhi ji yu xingfa xianjie wenti tanjiu (An exploration of problems of the nature and convergence with criminal punishment of detention for education after abolition of re-education through labour). Xibu faxue pinglun (Western Region Law Review), 1, 112-121.

Sun, Yunli. 2012. Shourong jiaoyu zhidu de fali fenxi (Legal Analysis of the System of Detention for Education). Journal of Guangxi Police Academy, 25(4), 49-52.

Tanner, M.S. 2000. State Coercion and the Balance of Awe: The 1983-1986 'Stern Blows' Anti Crime Campaign. The China Journal, 44, 93-125.

Trevaskes, S. 2002. Courts on the Campaign Path in China. Asian Survey, XLII (5), 673-693.

Trevaskes, S. 2003a. Public sentencing rallies in China: The symbolizing of punishment and justice in a socialist state. Crime, Law \& Social Change, 39, 359-382.

Trevaskes, S. 2003b. Yanda 2001: Form and strategy in a Chinese anti-crime campaign. Australian and New Zealand Journal of Criminology, 36 (3), 272-292.

Trevaskes, S. 2004. Propaganda work in the Chinese courts. Punishment and Society, 6(1), 521.

Trevaskes, S. 2007a. Courts and Criminal Justice in Contemporary China, New York: Lexington books.

Trevaskes, S. 2007b. Severe and Swift Justice in China. British Journal of Criminology, 47, 2341. 
Tucker, J., Xin Ren, and Sapio, F., 2010. Incarcerated sex workers and HIV prevention in China: Social suffering and social justice countermeasures. Social Science \& Medicine, 70(1), 123.

Wang, Jiancheng. 2000. Qiangzhi cuoshi (Coercive Measures). In Chen Guangzhong ed., Xingshi susongfa shishe wenti yanjiu (Research on the Issues in Implementation of the Criminal Procedure Law), Beijing: Zhongguo Falv Chubanshe (China Law Press), pp. 78-99.

Wang, Wei. 12 May 2015. Huang Haibo piaochang shijian nv zhujiao Liu Xinyu yishen huo xing liugeyue (Huang Haibo prostitution case actress Lui Xinyu sentenced at first instance to 6 months' imprisonment). Available from: http://news.qq.com/a/20150512/034876.htm [12 August 2015].

Wang, Yadong, Xia Chenghua, and Lei Dongsheng. 1997. Gong'an jiguan yao jiji canyu shehuizhuyi jingshen wenming jianshe (Public security organs must actively participate in construction of socialist spiritual civilization). Gong'an Yanjiu (Public Security Studies), 1(51), 20-22.

Wang, Yiqiong. 2014. 67 held after Dongguan sex trade expose. Global Times, 10 February. Available from: http://www.globaltimes.cn/content/841499.shtml [12 August 2015].

Watts, J. 2006. Outrage at Chinese prostitutes' shame parade. The Guardian (online), 6 December. Available from:

https://www.theguardian.com/world/2006/dec/06/china.jonathanwatts [12 August 2015].

Wong, C. 2013. Paying for Urbanization in china: challenges of municipal finance in the twenty-first century. In R. Bahl, J. Linn and D. Wetzel eds., Financing Metropolitan Governments in Developing Countries, Cambridge, Massachusetts: Lincoln Institute of Land Policy, pp. 273-308.

Wong, E. 2014. Red lights dim in China's sin city. New York Times, 6 March. Available from: http://www.nytimes.com/2014/03/07/world/asia/red-lights-dim-in-chinas-sincity.html?_r=0 [12 August 2015].

Wu, Lizhi. 2008. Lun 'yiren weiben' yu woguo xingshi fazhi (The 'Human-Oriented' outlook and the rule of law in criminal justice in China). Tiedao Jingguan Gaodeng Zhuanke Xuexiao Xuebao (Journal of Railway Police College), 18(1), 44-50.

Wu, Sunlin. 19 February 2014. Guangdong zhengxie weiyuan jianyi Guangzhou shuaixian tingyong shourong jiaoyu zhidu (Guangdong CPPCC member recommends that Guangzhou take the lead in stopping the use of detention for education). Nanfang Dushi Bao (Southern Metropolis Daily). Available from: http://news.sina.com.cn/c/2014-0219/040029504028.shtml [12 August 2015].

Xie, Ying. 2010. Cruel and unusual. News China. October Issue. Available from: http://www.newschinamag.com/magazine/cruel-and-unusual [12 August 2015]. 
Xie, Youping, and Jiang, Yong. 2007. Lun woguo yiren weiben de xingshi susong zhidu de yingyou jiegou (On the proper structure of the humanist (people as the basis) system of criminal procedure). Beifang Faxue (Northern Legal Science), 1(4), 80-89.

Xing, Shewei. 2014. Gong'an Bu yaoqiu gedi yanda huang du du (Ministry of Public Security demands that all regions strike hard against prostitution, gambling and drugs). Beijing News, 17 February. Available from: http://epaper.bjnews.com.cn/html/201402/17/content_495186.htm?div=0 [12 August 2015].

Xue, Bingni. 2014. Maiyin piaochang ke fa wubai huo wuqian, wangwang zhijie fa wuqian (Prostitutes and their clients can be fined either 500 or 5,000 and are often directly fined 5,000). Nanfang Dushi Bao (Southern Metropolis Daily), 14 May. Available from: http://epaper.oeeee.com/epaper/A/html/2014-05/14/content_3253843.htm?div=-1 [12 August 2015].

Yu, V. 2015. Published confessions stoke fears for lawyers held in Chinese crackdown. South China Morning Post (online), 19 July. Available from: http://www.scmp.com/news/china/policies-politics/Article/1841387/publishedconfessions-stoke-fears-lawyers-held-chinese [12 August 2015].

Zhan, Wei. 2005. Zhongguo dui maiyin piaochang renyuan shourong jiaoyu zhidu de yanjiu baogao (Research Report on China's System of Detention for Education of Prostitutes and Clients of Prostitutes). In Guo Jian'an and Zheng Xiaze eds., Xianzhi dui Renshen Ziyou de Xianzhi (To Refrain from the Restrictions on Personal Freedom). Beijing: Falv Chubanshe (Law Press), pp. 416-470.

Zhang, Jinya, Liu, Ziwen. 2014. Huang Haibo shourong qi man huoshi (Huang Haibo released after his period of detention expires). People's Daily Online, 1 December. Available from: http://legal.people.com.cn/n/2014/1201/c42510-26121742.html [12 August 2015]

Zi, Zhengfa. 2014. Sifa gaige beijing xia de xingshi hejie - xingshi sifa wenming de di san zhong moshi (Criminal reconciliation in the context of judicial reform: the third model of criminal judicial civilisation). Xueshu Tansuo (Academic Exploration), 12, 48-57.

Zou, Wei, and Shi, Jingnan. 2013. Gong'an Bu jiedu Gong'an Jiguan Banli Xingzheng Anjian Chengxu Guiding (Ministry of Public Security interprets the Regulations on the Procedures for Handling Administrative Cases by Public Security Organs). Caixin online, 5 January. Available from: http://china.caixin.com/2013-01-05/100479780.html [12 August 2015]. 


\section{University Library}

\section{- M M I N E R VA A gateway to Melbourne's research publications}

Minerva Access is the Institutional Repository of The University of Melbourne

Author/s:

Biddulph, S

Title:

Justice at the Margins: Notions of Justice in the Punishment of Prostitution

Date:

2017

Citation:

Biddulph, S. (2017). Justice at the Margins: Notions of Justice in the Punishment of Prostitution. Sapio, F (Ed.). Trevaskes, S (Ed.). Biddulph, S (Ed.). Nesossi, E (Ed.). Justice: The China Experience, Justice: The China Experience, (1), pp.312-355. Cambridge University Press.

Persistent Link:

http://hdl.handle.net/11343/254297 